\title{
PRZESTRZENNE ZRÓŻNICOWANIE WYNIKÓW WYBORÓW DO SEJMU Z 1957 ROKU
}

Zarys treści: $Z$ wyborów organizowanych w czasach PRL na uwagę zasługują przede wszystkim te z 1957 roku. Przeprowadzono je w okresie popaździernikowej odwilży, a władze nie miały specjalnych powodów, by je fałszować. Liberalna atmosfera sprzyjała wyborczej konkurencji, a oficjalne wyniki wyborów uwidoczniły znaczące zróżnicowanie polskiego społeczeństwa w ujęciu przestrzennym.

Słowa kluczowe: wybory z 1957 roku, przestrzenne zróżnicowanie, trwałość zachowań wyborczych, PZPR, okręgi wyborcze.

\section{Wstęp}

Porównanie przestrzennego zróżnicowania wyników polskich wyborów okresu międzywojennego (1918-1939) i postkomunistycznego (1989-2015) pokazuje bardzo wyraźną zbieżność ${ }^{1}$. Północny zachód kraju (w okresie międzywojennym Wielkopolska, Kujawy i Zagłębie Dąbrowskie, po 1989 roku także Dolny Śląsk, Pomorze Zachodnie oraz Warmia i Mazury) wykazywał szczególnie silne poparcie dla lewicy i liberałów. Regiony południowo-wschodnie (małopolskie, podkarpackie, podlaskie) zdominowane były przez sympatie dla partii prawicowych i konserwatywnych (Kowalski 2014). Wobec tej trwałości nasuwa się przypuszczenie, że omawiane przestrzenne zróżnicowanie postaw politycznych utrzymywało się także w czasach PRL. Potwierdzeniem dla tej tezy mogą być różnego rodzaju wskaźniki. Jednym z nich był wyższy udział członków PZPR w północno-zachodnich regionach Polski (Bartkowski 2003). Problemem może być natomiast udowodnienie tej prawidłowości na podstawie wyników wyborów, jakie w latach 1946-1988 były przeprowadzane w Polsce.

\footnotetext{
${ }^{1}$ Artykuł powstał w ramach projektu naukowego nr 2011/01/B/HS5/05898 pt. „Atlas Wyborczy Polski” finansowanego przez Narodowe Centrum Nauki.
} 


\section{Wybory w PRL}

Wybory przeprowadzane w czasach PRL nie były wolne i uczciwe, ich wyniki trudno uznawać za wiarygodne i oddające rzeczywiste postawy polityczne obywateli, a w związku z tym trudno na ich podstawie analizować przestrzenne zróżnicowanie zachowań wyborczych w Polsce (Zarycki 1997). Nie było swobody działalności partii politycznych, a listy wyborcze obejmujące wszystkie dopuszczone do startu w wyborach stronnictwa i środowiska ustalane były pod dyktando PZPR w ramach Frontu Jedności Narodu (później PRON). Wybory uzyskały charakter rytuału, a udział w nich był uważany za wyraz poparcia dla sprawujących władzę (układających listy wyborcze). Pomimo tych ograniczeń można przypuszczać, że władze posuwały się również do fałszowania wyborów, chcąc pochwalić się wysoką frekwencją wyborczą i jak największym poparciem dla kandydatów zaakceptowanych przez FJN. Pełną swobodę wypowiedzi, choć początkowo ograniczoną do $1 / 3$ składu sejmu oraz społeczną kontrolę liczenia głosów, polscy wyborcy uzyskali dopiero w 1989 roku.

Interesujące spostrzeżenia dotyczące wyborów w czasach PRL przedstawia w swym opracowaniu J. Bartkowski (2003). Analiza wyników czterech wytypowanych przez niego aktów wyborczych wykazała, że jedynie te z 1957 roku uwidoczniły dość wyraźne różnice w postawach wyborczych, przekładające się również na wyraźne zróżnicowanie przestrzenne w wynikach wyborów. W ogólnym zarysie (brak szczegółowej analizy kartograficznej) zróżnicowanie to przyjmuje bardzo podobny obraz jak ten z wyborów międzywojennych i wyborów po 1989 roku. Najsilniejsza kontestacja komunistycznej władzy miała miejsce na obszarze dawnej Galicji, najsłabsza na obszarze Górnego Śląska (czy raczej województwa katowickiego) oraz Ziem Zachodnich i Północnych. Różnica pomiędzy tymi obszarami w zakresie preferencji politycznych (skreślanie kandydatów z miejsc mandatowych) wynosiła ok. 10-15 pkt procentowych.

W pozostałych wyborach z czasów PRL tak wyraźnych oznak zróżnicowania przestrzennego już dostrzec nie można. Niektórzy badacze do wyjątków zaliczają wybory odbywające się po stanie wojennym. Były to wybory rad narodowych z 1984 i 1988 roku, wybory do sejmu z 1985 roku i referendum z 1987 roku. Frekwencja w tych głosowaniach była najniższa w historii PRL, a dodatkowo silnie zróżnicowana pod względem przestrzennym w układzie 49 województw. Według badaczy, wobec wezwań opozycji do bojkotu, wysokość frekwencji można potraktować jako poziom poparcia dla ówczesnych władz, choć oczywiście należy podchodzić z dużą ostrożnością do oficjalnych informacji o jej wysokości. Zdaniem T. Zaryckiego (1997), pod względem przestrzennego zróżnicowania mogła ona odpowiadać prawdzie, inny (znacznie niższy) mógł być natomiast jej rzeczywisty poziom. Zdaniem niektórych badaczy (np. Ostrowski i Przeworski 1996) wysokość wyborczej absencji z tamtych lat jest odwrotnie proporcjonalna do wyniku KO „Solidarność” z 1989 roku. 
Wyniki wyborów z 1985 i 1987 roku wskazują, że teza ta może być słuszna jedynie w odniesieniu do dużych ośrodków miejskich (Gdańsk, Łódź, Poznań, Warszawa, Kraków, Szczecin, Lublin, Toruń), które w latach 80. charakteryzowały się niską frekwencją wyborczą, natomiast w 1989 roku silnie poparły opozycję. Prawidłowość ta nie uzyskuje już takiego potwierdzenia w mniej zurbanizowanych województwach, gdzie niezależnie od regionalnej lokalizacji i późniejszych sympatii politycznych, frekwencja wyborcza należała do najwyższych, tylko nieznacznie różnicując się pod względem przestrzennym (Obwieszczenie... 1985, 1987).

\section{Uwarunkowania wyborów z 1957 roku}

Uwzględniając powyższe spostrzeżenia wydaje się, że z wyborów organizowanych w latach 1946-1988 na uwagę zasługują przede wszystkim te z 1957 roku. Przeprowadzono je w okresie popaździernikowej odwilży, przy silnym entuzjazmie dla W. Gomułki i jego ekipy. Wybory stały się swego rodzaju plebiscytem popularności nowego rządu (Bartkowski 2003), a jego wyniku organizatorzy mogli być w miarę pewni. Władze nie musiały więc uciekać się do fałszerstw (a przynajmniej nie na taką skalę jak wcześniej lub później). Front Jedności Narodu, jako podstawa formowania list wyborczych, dawał im pod tym względem dodatkową pewność, gdyż nie pozwolono zarejestrować list reprezentujących inne środowiska. Wzywano jednocześnie do powszechnego udziału w wyborach, mającego być świadectwem poparcia dla nowej ekipy władzy. Apelowano również do głosowania bez skreśleń, tak by osoby znajdujące się na pierwszych miejscach list wyborczych (miejsca mandatowe), a więc posiadających szczególne namaszczenie rządzącej ekipy, bez problemu dostały się do sejmu. Z tym apelem wystąpił również kardynał Stefan Wyszyński, dążący do ustanowienia modus vivendi między Kościołem a komunistycznymi władzami. Dodatkowym motywem skłaniającym Kościół do tego typu apeli było przyznanie kilku miejsc mandatowych reprezentantom Ruchu „Znak”. Z drugiej strony społeczeństwo wciąż żyło atmosferą liberalizmu, uruchomionego niedawnym zrywem społecznym i zmianą na szczytach władzy. Na dalszych miejscach list FJN (niemandatowych) umieszczano dodatkowych kandydatów (tab. 1), co nie było praktykowane w poprzednich wyborach. Ten dodatkowy wybór (podobnie jak dodanie kandydatów ruchu „Znak”) miał uwiarygodniać liberalizację systemu, by pokazać, iż jest jakiś wybór między kandydatami. Bardzo często na żądanie różnych grup społecznych na tych dalszych miejscach pojawiali się kandydaci bardziej niezależni. By oddać na nich głos należało skreślać osoby znajdujące się na miejscach mandatowych. Liberalna atmosfera sprzyjała wyborczej konkurencji w ramach tak zatwierdzonych list. Tym bardziej, że kandydaci reprezentowali różne stronnictwa i środowiska, a wśród nich zdarzały się osoby o niezależnych poglądach. 
Tabela 1

Wyniki wyborów w okręgu wyborczym nr 7 z siedzibą w Bielsku Podlaskim (powiaty: Bielsk Podlaski, Hajnówka, Łapy,

Wysokie Mazowieckie, Siemiatycze)

\begin{tabular}{|c|l|c|c|}
\hline $\begin{array}{c}\text { Miejsce } \\
\text { na } \\
\text { liście }\end{array}$ & \multicolumn{1}{|c|}{ Kandydat } & $\begin{array}{c}\text { Odsetek } \\
\text { głosów }\end{array}$ & Ugrupowanie \\
\hline \multicolumn{4}{|c|}{ Miejsca mandatowe } \\
\hline 1 & J. Ryznar & 84,49 & ZSL \\
\hline 2 & D. Sańko-Sawczenko & 75,95 & PZPR \\
\hline 3 & J. Kowal & 87,68 & SD \\
\hline 4 & M. Demianowicz & 75,73 & PZPR \\
\hline 5 & J. Maciejuk & 77,51 & PZPR \\
\hline \multicolumn{4}{|l|}{ Miejsca niemandatowe } \\
\hline 6 & Sz. Szymaniuk & 8,93 & PZPR \\
\hline 7 & A. Zin & 11,09 & PZPR \\
\hline 8 & J. Mazurek & 24,63 & ZSL \\
\hline
\end{tabular}

Źródło: S. Iwaniuk (1996).

Ordynacja wyborcza ustanawiała okręgi wielomandatowe. Mandat poselski otrzymywali kandydaci, którzy uzyskali największe poparcie, pod warunkiem, że przekroczyło ono $50 \%$. Wyboru pomiędzy kandydatami można było dokonywać za pomocą skreślania niechcianych osób. Gdy liczba nieskreślonych kandydatów na pojedynczej karcie wyborczej była większa od liczby mandatów przypadających na okręg, o otrzymaniu pojedynczego głosu decydowało miejsce na liście (Ordynacja wyborcza do Sejmu... 1956). Z tego powodu władze wzywały do głosowania bez skreśleń. W takim wypadku, gdy na przykład mandatów w okręgu było pięć, a kandydatów siedmiu, pojedyncze głosy przypadały pięciu pierwszym kandydatom umieszonym na liście. Nie trzeba dodawać, że najbardziej pożądani przez władze kandydaci na posłów znajdowali się na tych właśnie miejscach.

Hasła głosowania bez skreśleń (poparte przez Kościół) oraz selekcja kandydatów zgłaszanych do miejsc niemandatowych dawały władzy poczucie kontroli nad sytuacją i były gwarantem względnej uczciwości liczenia głosów. Dodanie kandydatów niemandatowych oraz polityczny wachlarz w ramach poszczególnych list pozwalały natomiast wyborcom (jeżeli tylko chcieli) różnicować poparcie w zależności od własnych przekonań.

Procedura zatwierdzania list wyborczych FJN zapewniała PZPR sejmową większość. Według przyznanych miejsc mandatowych ugrupowanie to miało posiadać $52 \%$ posłów, ZSL - 26\%, SD - 8,5\%, natomiast bezpartyjni (w tym „Znak”) 14\%. Wezwanie do głosowania bez skreśleń ograniczało możliwość 
dokonania zmiany w tym układzie. Dodatkowym zabezpieczeniem było umieszczanie kandydatów PZPR także na miejscach niemandatowych (tab. 1). Choć strategia ta przyniosła władzom zamierzony skutek (do sejmu nie dostała się tylko jedna osoba z miejsca mandatowego), nie udało się narzucić tego schematu głosowania wszystkim wyborcom. Pewna ich część w ogóle nie poszła na wybory, inni dokonywali skreśleń, dając szanse kandydatom $\mathrm{z}$ miejsc niemandatowych. Wielu różnicowało poparcie dla kandydatów z miejsc mandatowych (skreślając niektóre osoby) w zależności od ich przynależności partyjnej i poglądów.

Pod wpływem wyżej opisanych okoliczności wybory stały się okazją do ujawnienia znaczącego zróżnicowania polskiego społeczeństwa (wyborców) w ujęciu przestrzennym. Analiza tego zróżnicowania wykazuje, że nawiązuje ono wyraźnie do przestrzennego zróżnicowania wyników wyborów odbywających się w innych okresach, zarówno wcześniejszych (okres międzywojenny), jak i późniejszych (po 1989 roku).

\section{Frekwencja wyborcza}

W przypadku frekwencji wyborczej widać wyraźne przestrzenne zróżnicowanie w skali kraju (rys. 1). Okręgi z najwyższą frekwencją, przekraczającą 96\%, położone były prawie bez wyjątku na zachodzie. W województwie szczecińskim, zielonogórskim i koszalińskim stanowiły większość. Rekord padł w okręgu w Szczecinku, gdzie frekwencja sięgnęła prawie 97\%. Okręgi z najniższą frekwencją skupiały się w południowo-wschodniej części kraju, w województwach łódzkim, krakowskim, kieleckim, lubelskim, warszawskim i opolskim, gdzie aż w 13 okręgach na wybory poszło mniej niż 92\% wyborców (w lubelskim w większości okręgów). Rekordowo niską frekwencję (80,5\%) zanotowano w Tychach.

\section{Rezultat kandydatów PZPR}

Podobny układ miało zróżnicowanie uśrednionego poparcia dla kandydatów PZPR z miejsc mandatowych (rys. 2). W Polsce północno-zachodniej w większości okręgów przekroczyło ono 90\%. W dwóch okręgach Zagłębia Dąbrowskiego, w Bytomiu i Szczecinie było wyższe niż 97\%. Z drugiej strony, w dużej części okręgów południowo-wschodniej Polski uśrednione poparcie dla kandydatów PZPR z miejsc mandatowych było niższe niż 80\%. W województwie krakowskim i rzeszowskim, czyli na obszarze d. Galicji, dotyczyło to większości okręgów. Najniższe poparcie dla PZPR $(61,3 \%)$ zanotowano jednak w okręgu wieluńskim (Obwieszczenie... 1957). 


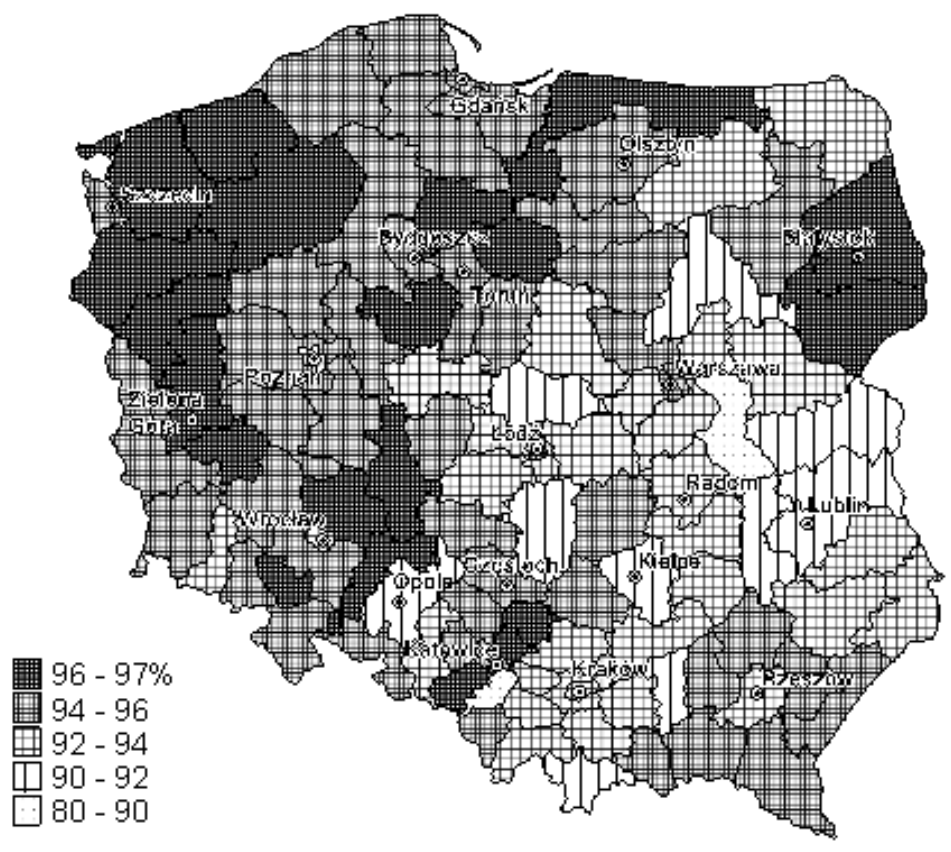

Rys. 1. Frekwencja w wyborach do sejmu w 1957 roku według okręgów wyborczych Źródło: opracowanie własne

Jeden kandydat PZPR z miejsca mandatowego uzyskał mniej niż 50\% głosów, co było wyjątkowym wypadkiem w dziejach PRL. Był nim Jan Antoniszczak, startujący w okręgu wyborczym Nowy Sącz, powszechnie krytykowany za stalinowskie poglądy oraz poparcie dla kolektywizacji. Uzyskał poparcie jedynie 45,8\% wyborców. Według obowiązującej ordynacji nie mógł zasiąść w sejmie. Na jego miejsce wybrano w wyborach uzupełniających Zbigniewa Gertycha, który w pierwszym głosowaniu startował z miejsca niemandatowego, uzyskując 38,1\% głosów. On również był kandydatem PZPR, ale reprezentował zupełnie inne poglądy. W czasie wojny był żołnierzem AK, a w chwili wyborów dyrektorem Instytutu Sadownictwa w Brzeznej w powiecie nowosądeckim. W dodatkowych wyborach uzyskał $61,86 \%$ głosów i wygrał z jedynym kontrkandydatem, Tadeuszem Hodakowskim (także PZPR) (Obwieszczenie... 1957; Z. Gertych wybrany na posła... 1957; Kępiński i Kilar 1985; Kwiek 2000; Drabik 2011). Nie jest wykluczone, że apel do głosowania bez skreśleń działał tym razem na jego korzyść, gdyż na liście wyborczej zajmował pierwsze miejsce. Trzeba jednak pamiętać, że Z. Gertych cieszył się rzeczywistą popularnością w okręgu wyborczym, co objawiło się już przy pierwszym głosowaniu. Wtedy jednak musiał podzielić się głosami z innym popularnym kandydatem z miejsca niemandatowego, bezpartyjnym nauczycie- 
lem Franciszkiem Wyśmierskim² ${ }^{2}$ (35,82\% głosów). W wyborach uzupełniających Gertych uzyskał przede wszystkim poparcie mieszkańców wsi, gdzie jego działalność w Instytucie Sadownictwa była na obszarze Sądecczyzny szczególnie ceniona. Jego kontrkandydat - T. Hodakowski mógł liczyć przede wszystkim na głosy mieszkańców Nowego Sącza, gdzie był znany jako organizator i dyrektor Technikum Gastronomicznego oraz Technikum Samochodowego. Obaj kandydaci stoczyli równorzędną walkę o mandat, co było ewenementem w dziejach PRL. To samo można powiedzieć o całości wyborów na Sądecczyźnie. Na jeden z trzech mandatów nie został wybrany kandydat wskazany przez władze (Antoniszczak), lecz ten, który bardziej odpowiadał wyborcom (Gertych). Powtórzone wybory były żywo relacjonowane w prasie krajowej, budziły również zainteresowanie zagranicznych korespondentów (Nowosadeccy kandydaci 1957; Stec 1957; Turek 1957).

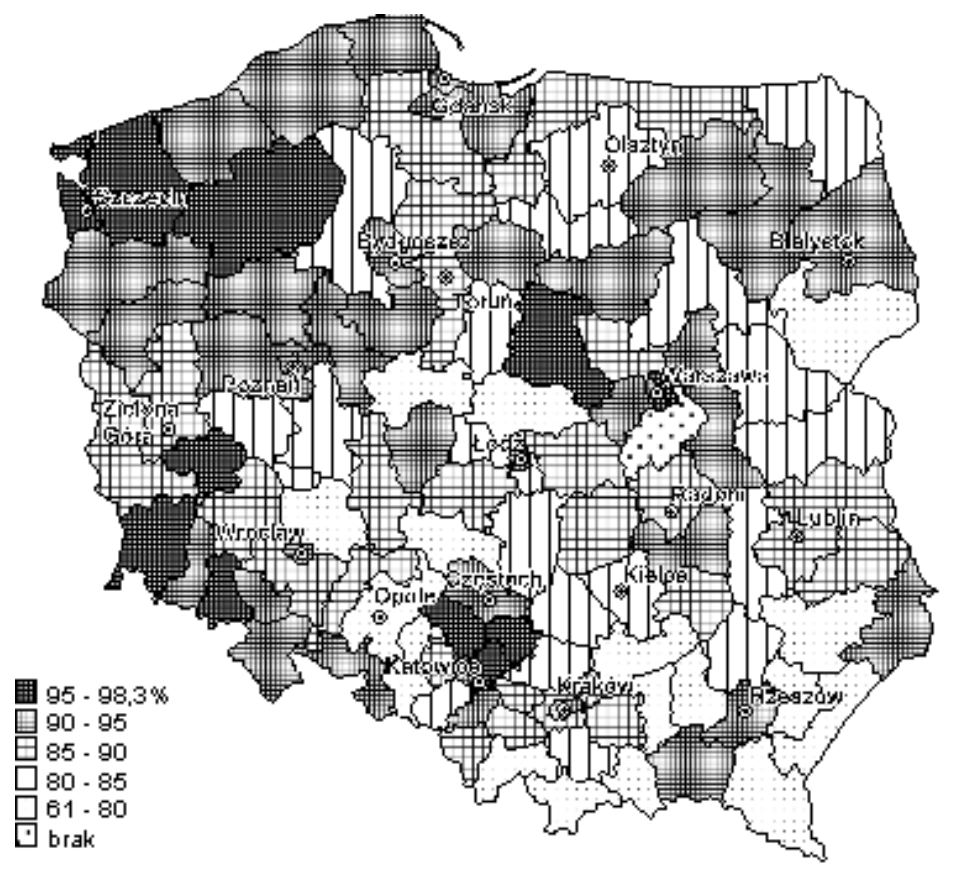

Rys. 2. Średnie poparcie dla kandydatów PZPR z miejsc mandatowych według okręgów wyborczych w 1957 roku Źródło: opracowanie własne

${ }^{2}$ Franciszek Wiśmierski był geografem, nauczycielem II LO w Nowym Sączu. Przed wojną mieszkał w Galicji Wschodniej, a w czasie wojny działał w strukturach polskiego państwa podziemnego na tamtych obszarach, m.in. jako przewodniczący Powiatowej Komisji Oświaty i Kultury w Czortkowie (pseudonim „Sterski”). Po wojnie opublikował kilka artykułów, m.in. „Globusie składany” w „Geografii w szkole” (Wiśmierski 1955) i o tajnym nauczaniu w powiecie czortowskim (Wiśmierski 1970). 


\section{Poparcie dla kandydatów z miejsc niemandatowych}

Podobne, co w przypadku głosów na PZPR, zróżnicowanie, lecz z odwróconymi wartościami dotyczyło wysokości poparcia dla najlepszych kandydatów z miejsc niemandatowych (rys. 3), którzy często także reprezentowali PZPR. Żaden $\mathrm{z}$ nich nie uzyskał miejsca $\mathrm{w}$ sejmie $\mathrm{w}$ pierwszym głosowaniu (Zbigniewowi Gertychowi udało się to dopiero w wyborach uzupełniających), lecz sam fakt udzielenia im poparcia przez znaczną część wyborców (pomimo popularności ekipy Gomułki) był świadectwem niezależności poglądów i opozycji wobec dominującej linii politycznej. Przestrzenne zróżnicowanie tego zjawiska dowodzi jednocześnie utrzymywania się silnych regionalnych różnic $w$ postawach politycznych Polaków. Najwyższe poparcie kandydaci ci uzyskiwali w centralnej i południowo-wschodniej części kraju. W dziewięciu okręgach wyborczych poparcie dla najlepszego kandydata $\mathrm{z}$ miejsca niemandatowego przekroczyło $30 \%$. Większość $\mathrm{z}$ nich znajdowała się w województwie krakowskim lub rzeszowskim, a więc na obszarze d. Galicji. W okręgu wyborczym w Sanoku Stanisław Gruczyński uzyskał nawet 50,5\% głosów, nie dało mu to jednak miejsca w sejmie, gdyż kandydaci mandatowi uzyskali lepsze rezultaty (najniższe poparcie w tej grupie wyniosło 55,5\%) (Obwieszczenie... 1957).

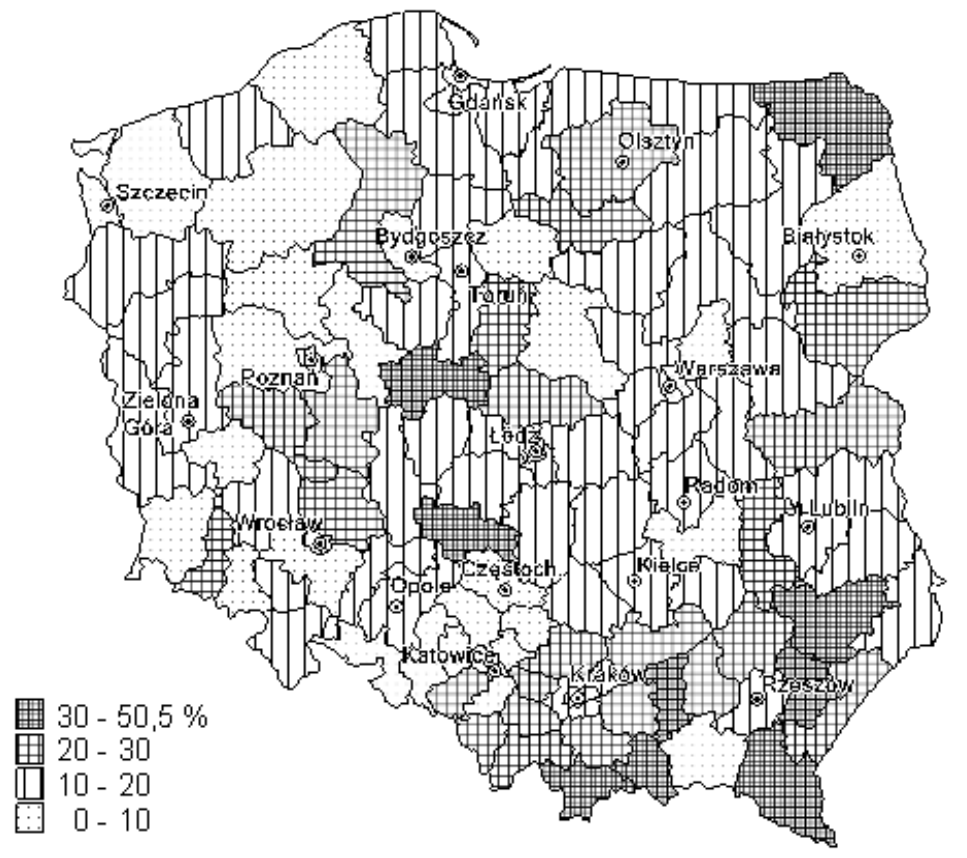

Rys. 3. Poparcie dla najlepszego kandydata z miejsca niemandatowego według okręgów wyborczych w 1957 roku

Źródło: opracowanie własne 


\section{Rywalizacja międzypartyjna}

W ramach rywalizacji kandydatów o miejsca mandatowe także widać zróżnicowanie przestrzenne. W skali całego kraju reprezentanci PZPR uzyskiwali przeciętnie niższe poparcie niż kandydaci innych ugrupowań: PZPR - 87,95\%, ZSL - 89,17\%, SD - 90,80\%, bezpartyjni - 94,26\% (Wiatr 1959). Względnie słaby ogólnopolski rezultat PZPR wiązał się również z wynikami rywalizacji w ramach list okręgowych. Na 118 okręgów wyborczych tylko w 14 uśredniony rezultat kandydatów tego ugrupowania z miejsc mandatowych był najlepszy (rys. 4). W kilku kolejnych jedynie pojedynczy, szczególnie popularni kandydaci PZPR, uzyskiwali w okręgu największą liczbę głosów (najmniej skreśleń). Dotyczyło to m.in. Władysława Gomułki (Warszawa-Praga) - 99,44\%, Mariana Spychalskiego (Poznań) - 97,92\% czy Oskara Lange (Warszawa-Stare Miasto) - 97,35\% (Obwieszczenie... 1957). Były to najczęściej osoby reprezentujące liberalne lub patriotyczne skrzydło partii. Wysokie dla nich poparcie, w połączeniu z relatywnie niskim poparciem dla pozostałych kandydatów PZPR $\mathrm{z}$ miejsc mandatowych (często było to kilka osób) w tym okręgu, powodowało, że $\mathrm{z}$ uwagi na uśrednione poparcie lepsze były inne ugrupowania lub bezpartyjni. Uwidacznia się to, gdy to relatywne zwycięstwo kandydatów PZPR porównamy z wynikami ich kolegów partyjnych na miejscach mandatowych $\mathrm{w}$ innych okręgach oraz wynikami kandydatów $\mathrm{z}$ miejsc niemandatowych w tych samych okręgach (rys. 2-3). W kilku okręgach prowadzenie kandydatów PZPR wydaje się być w związku z tym nie tyle skutkiem silnej dla nich sympatii, co słabego poparcia dla kandydatów innych opcji z miejsc mandatowych. $\mathrm{Ci}$ ostatni byli bowiem bardzo często skreślani, by dać szanse popularnemu kandydatowi z miejsca niemandatowego. Tak było z pewnością we wspomnianym powyżej okręgu sanockim oraz $\mathrm{w}$ okręgach suwalskim, jarosławskim, bocheńskim czy chrzanowskim. Być może tak samo, choć w mniejszym zakresie, było również w pozostałych. W zasadzie jedynym miejscem, gdzie kandydaci PZPR uzyskali wysoki, a jednocześnie najlepszy wynik w okręgu, przy jednocześnie słabym poparciu dla kandydatów z miejsc niemandatowych był okręg pilski w województwie poznańskim. W 1989 roku na tym samym mniej więcej obszarze (województwo pilskie) wybrano - jako jedynego w kraju - senatora nie reprezentującego KO „Solidarność”. Formalnie był on kandydatem niezależnym, cieszył się jednak wsparciem ówczesnych władz (Dudek 2013).

\section{Podsumowanie}

Eksperyment „liberalnych” wyborów roku 1957 unaocznił polskim komunistom, że nawet $\mathrm{w}$ momencie chwilowej popularności mają $\mathrm{w}$ społeczeństwie słabsze poparcie niż przedstawiciele stronnictw koalicyjnych (ZSL, SD). 


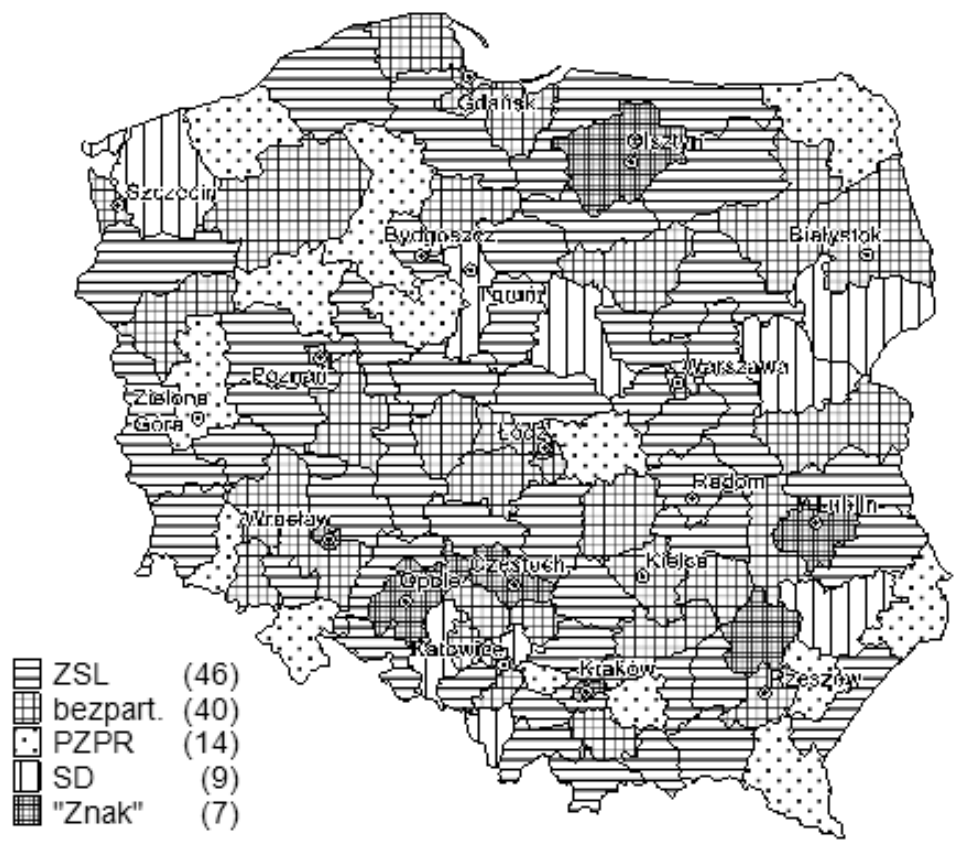

Rys. 4. Ugrupowania uzyskujące najlepsze średnie wyniki w okręgu dla kandydatów z miejsc mandatowych w wyborach do sejmu 1957 roku

Źródło: opracowanie własne

Jeszcze gorzej wypadali na tle kandydatów bezpartyjnych (w tym z Ruchu „Znak”). Nic więc dziwnego, że w kolejnych wyborach organizowanych w PRL możliwość konkurencji pomiędzy kandydatami i ugrupowaniami została praktycznie wyeliminowana, a wyniki podawane do publicznej wiadomość odbiegały od rzeczywistych rezultatów głosowania. Z tego powodu jedynie wybory z 1957 roku mogą być świadectwem utrzymującego się przestrzennego zróżnicowania zachowań wyborczych Polaków. W swym głównym zarysie (lewicowa Polska północno-zachodnia, antylewicowa Polska południowo-wschodnia) nawiązywało ono do prawidłowości obserwowanych w okresie międzywojennym oraz do wyborów z 1989 roku i późniejszych. Można to uznać za kolejny dowód na trwałość podziałów politycznych w Polsce w ujęciu przestrzennym. Ich podłoże musiało pod wieloma względami zostać uformowane w XIX wieku, gdyż do istniejących ówcześnie granic politycznych nawiązuje ich dzisiejszy kształt przestrzenny. $Z$ jednej strony mamy obszary należące niegdyś do państwa pruskiego, z drugiej dawne prowincje monarchii rosyjskiej (Królestwo Kongresowe) i austriackiej (Królestwo Galicji). 


\section{LITERATURA}

Bartkowski J., 2003, Tradycja i polityka. Wptyw tradycji kulturowych polskich regionów na współczesne zachowania społeczne $i$ polityczne, Wydawnictwo Akademickie „ŻAK”, Warszawa.

Drabik S., 2011, Wojewódzka organizacja partyjna PZPR w Krakowie w październiku 1956 i w okresie wyborów w styczniu 1957 roku, „Pamięć i Sprawiedliwość”, 1(17), s. 247-261.

Dudek A., 2013, Historia polityczna Polski 1989-2012, Wydawnictwo Znak, Kraków.

Iwaniuk S., 1996, Białorusini w wyborach do Sejmu PRL II kadencji 1957 roku, „Białoruskie Zeszyty Historyczne”, 6, s. 130-165.

Kępiński A., Kilar Z., 1985, Kto jest kim w Polsce inaczej, t. 2, Czytelnik, Warszawa.

Kowalski M., 2000, Geografia wyborcza Polski. Przestrzenne zróżnicowanie zachowań wyborczych Polaków w latach 1989-1998, IGiPZ PAN, Warszawa.

Kowalski M., 2014, Czy Wielkopolska była prawicowa? Przestrzenne zróżnicowanie zachowań wyborczych w Polsce w latach dwudziestych $X X$ wieku, „Prace i Studia Geograficzne”, 54, s. 89-105.

Kwiek J., 2000, Przebieg wyborów do Sejmu w styczniu 1957 roku w województwie krakowskim, „Studia Historyczne”, 43(1), s. 105-124.

Nowosadeccy kandydaci, 1957, „Dziennik Polski”, 65, s. 1 i 2.

Obwieszczenie Państwowej Komisji Wyborczej z dnia 22 stycznia 1957 roku o wynikach wyborów do Sejmu Polskiej Rzeczypospolitej Ludowej przeprowadzonych dnia 20 stycznia 1957 roku, 1957, „Monitor Polski”, 5.

Obwieszczenie Państwowej Komisji Wyborczej z dnia 15 października 1985 roku o wynikach wyborów do Sejmu Polskiej Rzeczypospolitej Ludowej przeprowadzonych dnia 13 października 1985 roku, 1985, „Monitor Polski”, 28.

Obwieszczenie Centralnej Komisji do Spraw Referendum z dnia 30 listopada 1987 roku o wyniku referendum ogólnokrajowego przeprowadzonego dnia 29 listopada 1987 roku, 1987, „Monitor Polski”, 34.

Ostrowski K., Przeworski A., 1996, The structure of partisan conflicts in Poland, [w:] Jasinska-Kania A., Raciborski J. (red.), Naród - Władza - Społeczeństwo, Wydawnictwo Naukowe Scholar, Warszawa, s. 185-206.

Ordynacja wyborcza do Sejmu Polskiej Rzeczypospolitej Ludowej. Ustawa z dnia 24 października 1956 roku (Dz.U., nr 47).

Stec T., 1957, Duze zainteresowanie prasy krajowej i zagranicznej wyborami w Nowym Saczu, „Dziennik Polski”, 65, s. 1.

Turek Z., 1957, Co wskazuje przedwyborczy barometr. Telegram z Nowego Sacza, „Dziennik Polski”, 63, s. 3 i 5.

Wiatr J.J., 1959, Niektóre zagadnienia opinii publicznej w świetle wyborów 1957 i 1958 roku, PWN, Warszawa.

Wiśmierski F., 1955, Globus sktadany, „Geografia w szkole”, 6, s. 326-329.

Wiśmierski F., 1970, Z dziejów szkolnictwa polskiego na ziemiach wschodnich w okresie II wojny światowej (Tajne nauczanie $w$ powiecie czortkowskim), „Przegląd Historyczno-Oświatowy”, 1, s. 107-125.

Z. Gertych wybrany na posła w ponownych wyborach w Nowym Saczu, 1957, „Życie Radomskie”, 68.

Zarycki T., 1997, Nowa przestrzeń społeczno-polityczna Polski, EUROREG, Warszawa. 


\title{
SPATIAL DIFFERENTIATION OF RESULTS OF THE POLISH PARLIAMENTARY ELECTIONS 1957
}

\begin{abstract}
When comparing the spatial differentiation of results of elections from the inter-war period (1918-1939) and the post-communist period (1989-2015), one sees a very clear similarity between the two (Kowalski, 2014). In the north-western part of the country the electoral preferences are with the left or the liberals, while in the south-eastern part - with the right.
\end{abstract}

Given the persistence of this spatial setting, a supposition arises that the spatial differentiation of the political attitudes existed also during the times of the socialist People's Poland. Lack of political freedom and electoral falsifications, performed by the communists, make the verification of this proposition quite difficult. Of the elections, organised in the socialist period, it is the ones, carried out in 1957, that deserve consideration, first of all. These elections were carried out in the short period of liberalisation after 1956, in conditions of an enthusiastic support for the new governing administration. The organisers of the elections could be fairly certain as to the outcome. That is why, side by side with the candidates, who were closely connected with the ruling establishment, also more independent persons, frequently enjoying high popularity in the society, were allowed to stand as candidates in these elections. In order to guarantee the victorious outcome, the authorities allowed for the formation of just a single list of candidates. The authorities lanced the appeal to vote for the candidates from the first places on the list, since it was on these places that the persons most convenient from the point of view of the establishment were listed. The few independent candidates were located at far-off positions. There was also an appeal for the possibly highest turnout at the elections, since this would constitute a signal of support for the new administration. These appeals were also shared by the Catholic Church in Poland.

Despite the limitations and constraints mentioned, the relatively liberal atmosphere was conducive to the electoral competition within the framework of the candidate lists approved. This was yet enhanced by the fact that candidates represented, formally at least, various political organisms (communists, peasant activists, democratic party, non-aligned candidates) and communities, and, as indicated, the lists also included, even though on far-off places, persons of independent orientations. In addition, the liberal atmosphere and the conviction of the ruling group that they must win, limited, it appears, the electoral falsifications to the minimum.

Owing to the advantageous social atmosphere and the appropriate construction of the lists of candidates, the communists could not lose these elections. Yet, in spite of this, the official results of the elections made visible the significant differentiation of the Polish society, both in global terms, and in space. The latter aspect represented a clear similarity to the spatial differentiation of the results of elections, taking place in other time periods, both the earlier ones (the interwar period) and those carried out later (after 1989).

Key words: election 1957, the spatial diversity, sustainability of electoral behavior, Polish United Workers Party, constituencies.

Dr hab. Mariusz Kowalski, prof. IGiPZ PAN Instytut Geografii i Przestrzennego Zagospodarowania PAN, Warszawa 